\title{
IMPLEMENTASI PERDA KABUPATEN GIANYAR TENTANG RETRIBUSI IZIN MENDIRIKAN BANGUNAN TERHADAP BANGUNAN PARIWISATA DI KABUPATEN GIANYAR
}

\author{
Putri Amelia Meirini, Wayan Wesna Astara, I Nyoman Sutama \\ Fakultas Hukum Universitas Warmadewa, Denpasar-Bali, Indonesia \\ putriamelia98j@gmail.com, wesnaastara58@gmail.com, sutamanyoman6@gmail.com
}

\begin{abstract}
Abstrak
Bagi para pendiri bangunan pariwisata di Kabupaten Gianyar harus mempunyai IMB dan membayar retribusi IMB sesuai dengan ketetapan pemerintah daerah (Bupati) Kabupaten Gianyar yang memiliki prosedur untuk pendirian bangunan pariwisata, karena usaha bangunan pariwisata merupakan salah satu bidang usaha penyediaan akomodasi yang diawasi oleh Pengawas Dinas Penanaman Modal dan Pelayanan Terpadu Satu Pintu Daerah Kabupaten Gianyar yang ditunjuk oleh Bupati dan Pegawai yang diberi tugas tertentu di bidang retribusi daerah sesuai dengan Peraturan Perundang-undangan. Rumusan masalah daam penelitian ini adalah Bagaimana pengaturan hukum perizinan pendirian bangunan pariwisata di kabupaten Gianyar serta implementasi Perda Kabupaten Gianyar Nomor 14 Tahun 01 tentang Retribusi Izin Mendirikan Bangunan khususnya terhadap bangunan pariwisata di kabupaten Gianyar? Jenis penelitian yang digunakan adalah jenis penelitian empiris, yaitu peneliti mengumpulkan data dengan cara langsung terjun ke lokasi penelitian yang bertempat di Dinas Penanaman Modal dan Pelayanan Terpadu Satu Pintu dan Kantor Satpol PP Kabupaten Gianyar. Hasil penelitian ini yaitu Izin Mendirikan Bangunan Pariwisata diberikan oleh pemerintah daerah melalui proses permohonan izin mendirikan bangunan pariwisata harus mengikuti prinsip- prinsip pelayanan prima dan murah atau terjangkau sesuai Peraturan Daerah No 14 Tahun 01, selanjutnya Penegakan hukum dalam pemberian Izin Mendirikan Bangunan dan pembayaran retribusi IMB di Kabupaten Gianyar dilakukan dengan memberikan sanksi kepada badan hukum atau masyarakat pemilik bangunan yang melanggar peraturan yang berlaku.
\end{abstract}

Kata Kunci: Objek wisata; Prosedur perizinan; Peraturan Daerah Gianyar

\begin{abstract}
Every founder of a tourism building in Gianyar Regency is required to have a Building Permit (IMB) and pay the levies according to the regional government (Bupati) of Gianyar Regency. The government establishes a procedure for the construction of tourism buildings because they are one of the business fields of providing accommodation which is supervised by the Supervisor of the Investment Service and One Stop Integrated Service of the Gianyar Regency area who is appointed by the Regent and employees who are assigned certain tasks in the area of regional retribution according to applicable legal rules. The issues the present examines are the legal arrangement for permits for the construction of tourism buildings in Gianyar regency and the implementation procedures for the Gianyar Regency Regional Regulation Number 14 of 01 concerning Building Permit Retribution, especially for tourism buildings in the district. The type of research used is the empirical research, which requires the researcher to collect data by coming to the research locus which is in the One Stop Investment and Integrated Service Office and the Civil Service Police Unit Office (Satpol PPl) of Gianyar. The results of the study reveal that the permit to construct tourism buildings is granted by the local government through the application process for building a tourism building permit which must follow the principles of prime and affordable service in accordance with Regional Regulation No. 14 of 01. Law enforcement in granting building permits and paying IMB levies in Gianyar Regency is executed out by giving sanctions to legal entities or building owners who violate the applicable regulations.
\end{abstract}

Keywords: Building Permit; Tourist attraction; Licensing procedure; Regional regulation 


\section{PENDAHULUAN}

Pada dasarnya pertumbuhan ekonomi masyarakat membangun di sebuah daerah kabupaten merupakan modal utama untuk meningkatkan. Menurut (Yulianita, 2009) bahwa setiap upaya pembangunan ekonomi daerah mempunyai tujuan utama untuk meningkatkan jumlah dan jenis peluang kerja untuk masyarakat daerah. dalam proses pelaksanaan pembangunan yang berkaitan dengan bangunan baik yang dilakukan penyandang dana maupun kekuasaan pemerintah di sebuah daerah memerlukan izin agar dalam membangun sebuah kekayaan memiliki izin serta kekuatan hukum dalam pemanfaatannya.

Provinsi Bali merupakan daerah dengan pertumbuhan pembangunan sarana pariwisata yang sangat pesat diantara beberapa Kabupaten Gianyar. Hal ini dibuktikan dengan maraknya pembangunan pondok wisata (villa), hotel, restoran, dan objek wisata yang ada di Kabupaten Gianyar. Untuk melaksanakan pembangunan sarana pariwisata di Kabupaten Gianyar tentunya wajib memiliki sertifikat izin dan wajib membayar retribusi IMB menurut prosedur yang ada pada Perda tentang Retribusi Izin Mendirikan Bangunan No. 14 Tahun 2012, akan tetapi dalam pelaksanaan kegiatan perizinan dan pemungutan retribusi IMB terhadap bangunan pariwisata di Kabupaten Gianyar dalam dua tahun terakhir masih ditemukannya pelanggaran yang dilakukan pemohon, pengusaha maupun masyarakat dalam pelaksanaan perizinan dan pemungutan retribusi IMB terhadap bangunan pariwisata ini yan g menjadi kendala. Menurut (Arcana, 2016) bahwa Tidak meratanya pertumbuhan pariwisata pada suatu destinasi tentu akan membebankan pengaruh, baik berupa dampak negative (cost) maupun benefit dari kegiatan pariwisata terhadap suatu daerah.

Menurut (Suryawati, 2018) ada beberapa startegi yang menjamin keberlangsungan pariwisata Bali adalah strategi yang mendukung keberlanjutan politik dan keamanan yang mendukung kenyamanan wisatawan, keberlanjutan ekonomi masyarakat Bali, keberlanjutan lingkungan (ekologis), serta keberlanjutan sosial dan budaya masyarakat. Contohnya Kabupaten Gianyar salah satu kabupaten di Indonesia dimana rumah tangga daerahnya mengurusi sendiri yang mempunyai kewenangan maka dari itu, Pemerintah Kabupaten Gianyar menciptakan peraturan yang mengenai penduduk daerahnya bagi kedamaian dan ketertiban masyarakat, salah satu bentuk penerbitan peraturannya adalah Peraturan Daerah Nomor 14 Tahun 2012 Tentang Retribusi Izin Mendirikan Bangunan. Dibentuknya peraturan daerah tersebut sebagai bentuk pengawasan dan upaya konkret eksekutif dan legislatif untuk mengendalikan dan mengawasi kegiatan pembangunan salah satunya sarana bangunan pariwisata di Kabupaten Gianyar.

Mengingat masih adanya pelanggaran yang dilakukan masyarakat atau pengusaha mengenai adanya kegiatan pembangunan tanpa adanya izin dan pembayaran biaya retribusi IMB terhadap bangunan pariwisata terlebih dahulu memuat dasar hukum pengurusan ijin mendirikan sebuah objek wisata. Pengetahuan tentang prosedur, sistem dan segala hal yang berakitan dengan permohonan izin mendirikan bangunan harus disebarkan secara merata, dalam hal ini karena harus sesuai dengan perda masih-masing daerah sehingga pemerintah daerah yang merupakan organ pemerintah paling dekat memiliki andil yang sangat besar dalam penyebaran informasi terkai (Sampebulu, 2020), selanjutnya menurut (Wijaya, 2015) telah melakukan penelitian terdahulu tentng Masa Depan Pariwisata Bali dalam penelitianya menyatakan bahwa Bali telah mengalami pasang surut, Tahun 1970an karena belum mendapat perhatian pemerintah. Penelitian ini bertujuan menjelaskan prosedur Pengaturan hukum perizinan pendirian bangunan pariwisata serta Implementasi Perda Kabupaten Gianyar Nomor 14 Tahun 2012 Tentang Retribusi Izin Mendirikan Bangunan khususnya terhadap bangunan pariwisata di Kabupaten Gianyar.

\section{METODE PENELITIAN}

Penelitian menggunakan jenis penelitian hukum empiris. Metode empiris merupakan suatu kegiatan yang dilakukan dengan cara penelitian secara langsung ke lapangan agar mendapat fakta yang akurat sebagaimana terdapat dalam kehidupan sehari-hari dan pendekatan masalah yang digunakan dalam penelitian ini adalah pendekatan sosiologis. Sumber data adalah Data primer dan data sekunder. Data primer yaitu data yang dilakukan dengan cara penelitian melalui wawancara atau penglihatan langsung. Adapun data primer tersebut adalah hasil wawancara langsung dari pelaksana Peraturan Daerah Kabupaten Gianyar Nomor 14 Tahun 2012 Tentang Retribusi Izin Mendirikan Bangunan, sedangkan Data sekunder yaitu data yang diperoleh kepada peneliti yang bersumber dari literatur dan media lainnya. Tekhnik pengumpulan data adalah Penelitian lapangan yaitu untuk memperoleh data 
berkaitan dengan permasalahan hukum yang akan dibahas dengan dilakukannya wawancara dengan responden, selanjutnya Penelitian pustaka yaitu untuk mengumpulkan data dilaksanakan dengan mempelajari buku, karya ilmiah, serta sumber bahan bacaan lain yang ada relevansinya dengan permasalahan yang ditelit. Teknik analisis data Teknik analisis data yang dipergunakan dalam penelitian ini adalah analisis deskriptif kualitatif. Analisis ini akan diarahkan pada uraian deskriptif mengenai bagaimana mekanisme perizinan berpengaruh terhadap fungsi awal lahan, yaitu kawasan lindung. Menggunakan teknik deskriptif analitis dapat dikembangkan pendeskripsian dan sekaligus interpretasi terhadap kondisi yang ditemui di lapangan (Praganingrum, 2013).

\section{HASIL DAN PEMBAHASAN}

\section{Pengaturan Hukum Perizinan Pendirian Bangunan Pariwisata}

Perizinan merupakan pemberian legalitas kepada seorang dalam kegiatan tertentu, baik dalam bentuk izin maupun tanda daftar usaha yang bersifat pengendalian yang dimiliki oleh Pemerintah terhadap kegiatan- kegiatan yang dilakukan oleh masyarakat. Selain itu terdapat juga pengertian izin dalam arti sempit maupun luas. Izin pariwisata yaitu merupakan gabungan dari pengertian izin dan usaha pariwisata yang dapat disimpulkan sebagai suatu aturan tindakan atau aturan tentang bagaimana suatu usaha jasa pariwisata dijalankan dan dilaksanakan. Penggolongan usaha industri pariwisata pada prinsipnya digolongkan menjadi dua bagian yaitu yang utama langsung dan yang sekunder tak langsung. Yang sekunder tak langsung adalah perusahaan- perusahaan yang memandang bahwa kegiatannya dalam pariwisata merupakan sumber penghasilan tambahan baginya sedangkan yang utama langsung adalah semua perusahaan yang bertujuan khusus memberikan dan menyajikan segala kegiatannya bagi perkembangan kepariwisataan dan yang kehidupannya benar- benar tergantung pada kegiatan- kegiatan pariwisata (Pendit, 2013).

Izin Mendirikan Bangunan (IMB) Pariwisata diserahkan dari pemerintah daerah, sedangkan pemerintah pusat memberikan izin mendirikan pembangunan gedung fungsi terpilih, lewat metode permohonan izin mendirikan pembangunan pariwisata perlu menyertakan posisi layanan terbaik dan murah atau teraih sesuai peraturan daerah No 14 Tahun 2012. Surat pernyataan pemegang yang diserahkan dari kekuasaan daerah merupakan bukti status kepemilikan bangunan salah satunya bangunan pariwisata.

Sesuai dengan hasil wawancara dengan informan Bapak I Made Artana Yasa Kepala Bidang Perizinan dan Non Perizinan A bahwa perihal sesuai perizinan dan nonperizinan mendapatkan pajak daerah yang ditetapkan oleh pejabat kekuasaan daerah terikat yang berkuasa. Sesuai dengan ketetapan perda No 14 Tahun 2012 kabupaten Gianyar Tentang Retribusi Izin Mendirikan Bangunan dalam penerapan pemenuhan pajak dilakukan awal mula pelimpahan surat izin kepada peminta, dan diserahkan langsung ke dana daerah berikut adalah pembayaran retribusi sesuai dengan bangunan per meter:

1. Rumah Tinggal: Rp. $8.500 / \mathrm{m} 2$

2. Tempat Usaha:

a) Biasa: Rp. $51.000 / \mathrm{m} 2$

b) Campuran: Rp. 68.000/m2

c) Gedung Pemerintah: Rp. 0,00/m2

3. Retribusi Tower: $1,75 \%$ dari RAB

4. Retribusi IMB Revisi: $10 \%$ dari Biaya Retribusi izin sebelumnya.

Dalam UUD 1945 pada pasal 23A menjelaskan bahwa "pajak dan pungutan lain yang bersifat memaksa untuk keperluan negara diatur dengan undang-undang". Untuk pungutan retribusi daerah diatas bersifat memaksa dan dapat dipaksakan. Aturan yang sekian memiliki makna sehingga seluruh pungutan yang membuat beban masyarakat mesti sepengetahuan masyarakat. Niscaya ada penataan publik tentang pajak daerah ke dalam ketetapan hukum karena tujuan diatas persoalan pajak dan retribusi daerah bersetuju dalam cangkupan konstitusional.

Untuk pemohon izin mendirikan bangunan pariwisata di Kabupaten Gianyar setiap perorangan atau suatu badan atau badan hukum atau oleh suatu pihak yang diberi kuasa diajukan sendiri, kepada Dinas Penanaman Modal dan Pelayanan Terpadu Satu Pintu (DPMPTSP) Kabupaten Gianyar dan ditembuskan kepada instansi sesuai ketentuan peraturan perundang- undangan yang berlaku.

Prosedur dalam pemberian izin mendirikan bangunan terhadap bangunan pariwisata dan membayar retribusi IMB di Kabupaten Gianyar adalah sebagai berikut: 
1. Pengajuan Permohonan

2. Mengisi Formulir Permohonan IMB

3. Kelengkapan Persyaratan Permohonan

4. Proses Penerbitan Izin

5. Biaya Retribusi

6. Pelaksanaan pembangunan.

\section{Implementasi Perda Kabupaten Gianyar No 14 Tahun 2012 tentang Retribusi Izin Mendirikan Bangunan terhadap Bangunan Pariwisata di Kabupaten Gianyar}

Implementasi sebagai suatu penerapan untuk mengukur atau menilai mengevaluasi apakah suatu kebijakan dan peraturan tercapai berproses dengan baik atau tidak, dengan begitu bahwa perihal dinilai apakah wajib ada evaluasi atau tidak terhadap agenda tersebut untuk mencapai tujuan kegiatan. Untuk itu implementasi sangat diperlukan dalam suatu tindakan atau penerapan dari selaras sistem yang sudah dirangkap secara detail dan terperinci (Rahmiati, 2017).

Untuk berjalannya Peraturan Daerah No 14 Tahun 2012

Tentang Retribusi Izin Mendirikan Bangunan maka diperlukan efektivitas hukum dimana efektivitas hukum dijalankan oleh pihak berwenang Satuan Polisi Pamong Praja (Satpol PP) Kabupaten Gianyar selaku penegak hukum peraturan daerah di daerah Kabupaten Gianyar. Maka dari itu dalam masyarakat perlu adanya efektivitas hukum. Bila membicarakan efektivitas hukum dalam masyarakat berarti membicarakan daya kerja hukum itu dalam mengatur dan/atau memaksa masyarakat untuk taat terhadap hukum yang mengkaji kaidah hukum yang harus memenuhi syarat, yaitu berlaku secara yuridis, sosiologis, dan secara filosofis (Ali, 2006).

Keberhasilan efektivitas hukum dalam kegiatan pengendalian IMB Pariwisata Dinas Penanaman Modal Pelayanan Terpadu Satu Pintu (DPMPTSP) Kabupaten Gianyar sangat memerlukan kerja sama dengan Satuan Polisi Pamong Praja (Satpol PP) Kabupaten Gianyar dimana Satpol PP selaku penegak Peraturan Daerah salah satunya Perda No 14 Tahun 2012 Tentang Retribusi Izin Mendirikan Bangunan di Kabupaten Gianyar. Agar tercapainya tujuan hukum diperlukan organisasi sekalipun pada hakikatnya bertugas untuk mengantarkan orang kepada tujuan hukum, namun masing- masing tetap berdiri sendiri- sendiri sebagai badan yang bersifat otonom. Melalui organisasi serta proses- proses yang berlangsung didalamnya, masyarakat menerima perwujudan dari tujuan- tujuan hukum. Dengan keputusan- keputusan pengadilan kondisi ketertiban keamanan dan sebagainya dengan perumusan undang-undang melalui organisasi di wujudkanlah tujuan hukum (Arliman, 2015).

Kabupaten Gianyar dalam pelaksanaan penegakan hukum, untuk pembayaran dan pemberian retribusi izin mendirikan bangunan dilaksanakan dengan pemberian hukuman bagi pemilik bangunan yang melanggar tata tertib. Untuk menciptakan kepastian keadilan dan ketertiban dalam terbentuknya selaras penerapan hukum sanksi bermaksud untuk tegaknya peraturan hukum yang mutlak oleh semua pihak, sehingga peraturan memperoleh berlakunya sesuai dengan yang ditetapkan. Apabila penerima izin tidak melakukan beban atau kewajiban yang diperoleh dalam izin tercantum, maka pemberi izinnya dapat dikenakan hukuman tata usaha karena per masingmasing izin mengandung kewajiban dan tanggung jawab yang harus dilaksanakan oleh pemilik izin.

Berdasarkan dengan hasil wawancara dengan informan Bapak I Gusti Ngurah Alit Arimbawa,SIP Kasi Penyidik dan Penyelidikan bahwa dalam penerapan yang melakukan perbuatan kepada pemilik bangunan yang melawan aturan yang berlangsung yaitu Satuan Polisi Pamong Praja (SATPOL PP) Kabupaten Gianyar tetapi harus mendapatkan surat tugas terlebih dahulu dari Seksi Pengawasan dan Penertiban Bangunan Dinas Penanaman Modal dan Pelayanan Terpadu Satu Pintu Kabupaten Gianyar sesuai Permendagri No 54 Tahun 2011 Tentang SOP Satpol PP sebagai berikut :

1. Landasana.

a . Melakukan penyuluhan kepada badan hukum dan masyarakat yang melanggar perda.

b . Melakukan pelaksanaan dan sosialisasi terhadap badan hukum

c. Tindakan Non penertiban

d. Penindakan Penertiban

2. Ketentuan hukum agar tidak menimbulkan korban atau kerugian pada pihak manapun harus dilaksanakan sesuai prosedur yang mempunyai landasan hukum dan tidak melanggar HAM 
3. Mematuhi dan mentaati peraturan daerah untuk pengarahan agar masyarakat tidak melanggar peraturan yang ada.

4. Pembinaan yaitu Pembinaan perseorangan dan pembinaan kelompok dilaksanakan dengan cara menuju kepada masyarakat dan badan hukum yang melanggar aturan daerah untuk dikasi tahu, bimbingan dan pengukuhan arti berharganya kepekaan dan ketaatan terhadap peraturan daerah dan pertimbangan kepala daerah.

5. Penindakan Preventif Non Yustisial

Berikut Satuan Polisi Pamong Praja tindakan yang dilakukan:

a. Perbuatan terhadap pelanggar peraturan daerah, terutama harus menandatangani surat pernyataan bersedia dan menyanggupi taat dan mematuhi serta melaksanakan dalam waktu 15 hari terhitung sejak penandatanganan surat pernyataan.

b. Syarat pernyataan jika tidak melakukan perihal itu diberi Surat teguran pertamadengan tenggang waktu 7 (tujuh) hari kedua Surat teguran kedua dengan tenggang waktu 3 (tiga) hari, terakhir Surat teguran ketiga dengan tenggang waktu 3 (tiga) hari;

c. Jika tidak melaksana kan atau tidak menepati surat peringatan tersebut, hendak diadukan kepada Penyidik Pegawai Negeri Sipil (PPNS) untuk membuat proses sesuai peraturan norma yang berlangsung.

6. Perbuatan Ketertiban ditemukan bahwa suatu kejadian yang berlangsung ialah pelanggaran aturan daerah yang tercatat dalam suatu peristiwa atau ruang lingkup tugas dengan norma yang membentuk kebenaran hukumnya dalam area kerjanya akan dilaksanakan oleh PPNS. Untuk bangunan Pariwisata yang melanggar peraturan Perda Kabupaten Gianyar No 14 Tahun 2012 akan dikenakan Sanksi Administratif yang diberikan oleh Dinas Penanaman Modal dan Pelayanan Terpadu Satu Pintu Kabupaten Gianyar sesuai dengan Perda Kabupaten Gianyar No 14 Tahun 2012. Perbulan dari retribusi yang terutang dan kurang bayar atau yang tidak bayar akan ditagih dengan menggunakan STRD (Surat Tagihan Retribusi Daerah) untuk hal wajib melakukan pungutan bagi yang kurang membayar atau tidak membayar tepat pada waktunya akan dikenakan sanksi administratif berupa bunga sebesar $2 \%$ (dua persen). Ketentuan yang berlaku selain pelanggar tersebut di laksanakan supaya badan hukum dan masyarakat mentaati pada norma dan keputusan yang berlaku. Jika tidak, pelanggar tersebut dilakukan juga demi kebutuhan masyarakat sendiri supaya masyarakat merasa bahwa izin mendirikan bangunan itu wajib dimiliki dan mesti membayar retribusi jika ingin membangun bangunan salah satunya terhadap bangunan pariwisata.

\section{SIMPULAN DAN SARAN}

\section{Simpulan}

Berdasarkan uraian sebelumnya peneliti dapat memberi simpulan yang pertama izin mendirikan bangunan pariwisata diberikan oleh pemerintah daerah melalui proses permohonan izin mendirikan bangunan pariwisata harus mengikuti prinsip- prinsip pelayanan prima dan murah atau terjangkau sesuai Peraturan Daerah No 14 Tahun 2012. Status kepemilikan bangunan pariwisata dibuktikan dengan surat bukti kepemilikan yang diberikan oleh pemerintah daerah. Yang kedua adalah Penegakan hukum dalam pemberian Izin Mendirikan Bangunan dan pembayaran retribusi IMB di Kabupaten Gianyar dilakukan dengan memberikan sanksi kepada badan hukum atau masyarakat pemilik bangunan yang melanggar peraturan yang berlaku. Sanksi tersebut bertujuan untuk tegaknya peraturan hukum, ditaati oleh semua pihak, jadi hukum dapat berlangsung secara efektif sesuai dengan kemauan, yaitu untuk mewujudkan keadilan dan ketertiban. Pelanggar ialah segmen terutama dalam asas, untuk terwujudnya selaras pelaksanaan hukum.

\section{Saran}

Ada beberapa hal yang disarankan oleh peneliti yang pertama adalah Sebaiknya dilakukan penyuluhan mengenai syarat Ijin Mendirikan Bangunan kepada pengusaha atau masyarakat agar masyarakat atau pengusaha dipisahkan sebelumnya telah menyiapkan penanganan Izin Mendirikan Bangunan terpenting izin mendirikan bangunan pariwisata oleh Dinas Penanaman Modal dan Pelayanan Terpadu Satu Pintu Bidang Perizinan dan Non Perizinan A Kabupaten Gianyar secara terus-menerus.yang kedua adalah Dalam rencana penataan dari pelanggaran ijin yang dilaksanakan bagi tuan gedung, proses penertiban dan pengawasan pemilik bangunan, aparat harus ditingkatkan lagi 
penertiban dan pengawasan bangunan untuk penerapan pemberian IMB di Kabupaten Gianyar dalam rencana pembenahan dari pelanggaran izin dilaksanakan oleh juragan gedung.

\section{DAFTAR PUSTAKA}

Ali, Z. (2006). Sosiologi Hukum. Sinar Grafika.

Arcana, K. T. P. (2016). Persepsi Masyarakat Lokal terhadap Perkembangan Akomodasi Pariwisata Studi Kasus: Desa Adat Seminyak, Kecamatan Kuta Kabupaten Badung, Bali. Analisis Pariwisata, 16(1), 52-60.

Arliman, L. (2015). Penegakan Hukum dan Kesadaran Masyarakat, Deepublish, . Deepublish.

Pendit, N. S. (2013). Ilmu Pariwisata, Sebuah Pengantar Perdana. Pradnya Paramita.

Praganingrum, T. I. (2013). Kajian terhadap Mekanisme Perizinan Pemanfaatan Lahan Tebing Tukad Ayung Kedewatan, Ubud, Gianyar. Kurva Teknik, 2(1), 50-68.

Rahmiati, D. (2017). Demokrasi, Ham dan Militer. Penelitian Politik LIPI, 14(2), 109-288.

Sampebulu, H. P. (2020). Penegakan Hukum Pemberian Izin Mendirikan Bangunan di Wilayah Bali. Mimbar Keadilan, 12(2), 238-251.

Suryawati, I. G. A. A. (2018). Strategi Pengembangan Pariwisata Bali Berkelanjutan Menghadapi Pasar Bebas Asean (afta). Jurnal Mitra Manajemen Online, 2(6), 680-692.

Wijaya, K. (2015). Masa Depan Pariwisata Bali ( Perspektif Permasalahan dan Solusinya ). Jurnal Riset Dan Ekonomi Dan Manajemen, 15(1), 118-135.

Yulianita, A. (2009). Analisis Sektor Unggulan dan Pengeluaran Pemerintah di Kabupaten Ogan Komering Ilir Anna. Jurnal Ekonomi Pembangunan, 7 (2), 70-85. 